\title{
Marie Hladká, Vladimír Hyánek*
}

\begin{abstract}
A Model of Donor Behaviour in the Czech Republic

The article examines the variables underlying an individual's decision to donate money to a nonprofit organisation. Based on a content analysis of leading foreign research, we identify and systematise factors that may affect an individual's decision to donate money, and we carry out an empirical testing in the Czech Republic. This article presents answers to the following question: which determinants affect significantly the willingness to donate? What does the model of donor behaviour look like on a selected sample? The authors apply a theoretical justification set of variables affecting donor behaviour to a questionnaire survey. Multiple linear regression analysis and binary logistic regression are used to determine which of the variables is the most influential. Among the statistically significant variables we can include: respondent's income, age, relations with the organisation and employees, the final beneficiary, religious orientation, affection, compassion and solidarity, gratitude, social responsibility and moral obligation, self-centred, feel good, pity, faith in justice.
\end{abstract}

Keywords: altruism, charitable giving, motive, non-profit organisation, philanthropy, pro-social behaviour

JEL Classification: C91, D01, D64

\section{Úvod}

Pro ověření platnosti vlivu všech předpokládaných faktorů, je nezbytné provést výzkum a definovat podstatu vztahu mezi jednotlivými faktory. Protože nejsou známy všechny možné proměnné, které vstupují do rozhodovacího procesu dárce, pracují autoři dále $\mathrm{v}$ textu a $\mathrm{v}$ provedeném výzkumu pouze $\mathrm{s}$ těmi, které byly $\mathrm{v}$ rámci content analysis identifikovány v nejvýznamnějších studiích. Cílem provedeného výzkumného šetření bylo identifikovat faktory, které mají u vybraného vzorku obyvatel České republiky vliv na rozhodnutí darovat finanční prostředky neziskovým organizacím a analyzovat tyto faktory ve vzájemných vztazích. Výzkum byl omezen na faktory ovlivňující dárcovství 1) nestátním neziskovým organizacím, 2) individuální a 3) peněžní (do výzkumu nebylo zahrnuto darování firemní).

Předkládaný článek prezentuje pouze některé výsledky výzkumného šetření. Jeho cílem je na základě výsledků regresní analýzy všech identifikovaných proménných vytvorit model dárcovského chováni v České republice

1 Článek je zpracován jako jeden z výstupů výzkumného projektu „Vliv veřejných financí na strukturu zdrojů a produkci neziskových instituci“" registrovaného u Grantové agentury České republiky pod evidenčním číslem GA14-06856S.

* Masarykova univerzita v Brně, Ekonomicko-správní fakulta (marie@hladka.cz; hyanek@econ.muni.cz). 


\section{Data a metody}

\subsection{Sběr dat}

Terénní šetření probíhalo v roce 2014, získáno bylo 442 vyplněných dotazníků. Základní soubor tvořili respondenti žijící na území České republiky starší osmnácti let. Autoři dále pracovali s tzv. dostupným (příležitostným) výběrem, závěry vyplývající z analýzy jsou tedy vztaženy pouze k tomuto výběrovému souboru. Výzkumné šetření tak bylo pojato jako předběžný průzkum či pilotní studie, která se používá k sondování v prostředí, o kterém máme málo poznatků a potřebujeme se v něm předběžně zorientovat. Vědomi si nereprezentativnosti výzkumného souboru nepředkládají autoři v práci závěry charakterizující českou společnost a její chování, ale závěry charakterizující pouze vybraný výzkumný vzorek. Výsledky výzkumu nejsou zobecnitelné. Pokud výzkum předloží závažná zjištění v podobě významného potenciálu některých faktorů, které lze určitým chováním - at' již státu, neziskových organizací či jednotlivce - ovlivňovat, může být toto výzkumné šetření chápáno právě jako předvýzkum toho, zda lze zvolenými postupy vlivy klíčových faktorů vůbec zkoumat, popř́ípadě jaké oblasti vlivu lze (bylo by žádoucí) nahlížet podrobněji.

\subsection{Základní charakteristika výzkumného vzorku}

Ve výzkumu byly větší měrou zastoupeny ženy (52,9\%) oproti mužům (47,1 \%). Největší zastoupení má věková skupina 25-34 let (29,9\%) a skupina 35-54 (28,1\%), průměrné stáří je 37,5 let. Nejpočetnější skupinou byli respondenti svobodní $(54,1 \%)$ a ženati/vdaní (34,4 \%). Nejpočetnější vzdělanostní kategorii tvořila skupina vyučen s maturitou/středoškolské vzdělání s 43,2\% a skupina vysokoškolské vzdělání s 40,7\%. Zastoupení dalších skupin se nachází pod hranicí $10 \%$ podílu. Více než třetinu výzkumného vzorku tvoří skupina s čistým př́ijmem 0 - 9.999 Kč. Druhou nejpočetnější kategorii tvoří skupina s průměrnou výší mzdy, tj. skupina 20.000 - 29.999 Kč s podílem 17, 9\%. Ve vzorku nalezneme více než třetinu respondentů, kteří se považují za věřící. Více než polovina respondentů je bez vyznání.

\subsection{Testované proměnné}

Dle teoretických poznatků autoři identifikují [více viz Hladká a Hyánek, 2016] tři základní skupiny motivů, které stojí v pozadí dárcovského rozhodování: altruismus, egoismus a investice. Naše rozhodnutí darovat však netvoří pouze vnitřní pohnutky, motivy, ale rovněž nespočet vnějších faktorů (v textu nazývány determinanty), které jsou dány prostředím, v němž žijeme, naším socio-ekonomickým či demografickým profilem. Autoři na základě content analysis vybrali nejčastěji identifikované a testované proměnné, které dále rozdělili do čtyř skupin na determinanty ekonomické, demografické, sociálni a situační. Přehled proměnných vstupujících do regresního modelu je zachycen $\mathrm{v}$ tabulce 1 . Některé $\mathrm{z}$ proměnných uvedených $\mathrm{v}$ tabulce 1 byly testovány ve více variantních zněních (proměnné mají více kódů), celkem do modelu vstupovalo 69 proměnných. 
Tabulka 1 | Kategorizace proměnných

\begin{tabular}{|c|c|c|c|}
\hline & Proměnná & Proměnná & \\
\hline \multirow[t]{12}{*}{$\begin{array}{l}\text { Altruistické } \\
\text { motivy }\end{array}$} & A emp empatie & $\begin{array}{l}\text { Ep_fin_1, Ep_fin_2 finanční } \\
\text { dostupnost }\end{array}$ & \multirow[t]{4}{*}{$\begin{array}{l}\text { Ekonomické } \\
\text { determinanty }\end{array}$} \\
\hline & A_nákl náklonost, sympatie & $\begin{array}{l}\text { Ep_dapo_1,Ep_dapo_2 } \\
\text { daňová politika }\end{array}$ & \\
\hline & A_ss soucit, solidarita & $\begin{array}{l}\text { Ep_vvs_1, Ep_vvs_2 velikost } \\
\text { veřejného sektoru }\end{array}$ & \\
\hline & A_slit slitování, lítost & $\begin{array}{l}\text { Ep_jine jiné ekonomické } \\
\text { proměnné }\end{array}$ & \\
\hline & A_úc úcta & Dp_vek věk & \multirow{8}{*}{$\begin{array}{l}\text { Demografické } \\
\text { determinanty }\end{array}$} \\
\hline & A_vdě vděčnost & Dp_pohl pohlaví & \\
\hline & A_sp společenská pravidla & Dp_vzd vzdělání & \\
\hline & $\begin{array}{l}\text { A_visp_1, A_visp_2 víra } \\
\text { ve spravedlnost }\end{array}$ & $\begin{array}{l}\text { Dp_sep socio-ekonomický } \\
\text { profil }\end{array}$ & \\
\hline & $\begin{array}{l}\text { A_přes_1, A_přes_2 } \\
\text { přesvědčení }\end{array}$ & $\begin{array}{l}\text { Dp_náb náboženská } \\
\text { orientace }\end{array}$ & \\
\hline & $\begin{array}{l}\text { A_socod_1, A_socod_2 } \\
\text { sociální odpovědnost }\end{array}$ & Dp_bydl bydliště & \\
\hline & $\begin{array}{l}\text { A_mopo_1, A_mopo_2 morální } \\
\text { povinnost }\end{array}$ & Dp_rodst rodinný stav & \\
\hline & A_nábp náboženská povinnost & Dp_polor politická orientace & \\
\hline \multirow[t]{15}{*}{$\begin{array}{l}\text { Egoistické } \\
\text { motivy }\end{array}$} & E_zisk príležitost zisku, odměny & $\begin{array}{l}\text { Sop_dobr_1, Sop_dobr_2 } \\
\text { dobrovolnictví a občanská } \\
\text { participace }\end{array}$ & \multirow[t]{2}{*}{$\begin{array}{l}\text { Sociální } \\
\text { determinanty }\end{array}$} \\
\hline & E_moc touha po moci & $\begin{array}{l}\text { Sop_mladi modely } \\
\text { a zkušenosti z mládí }\end{array}$ & \\
\hline & E_sebe sebestřednost & $\begin{array}{l}\text { Sip_efpř_1, Sip_efpř_2 efekt } \\
\text { přihlížejících }\end{array}$ & \multirow[t]{7}{*}{$\begin{array}{l}\text { Situační } \\
\text { determinanty }\end{array}$} \\
\hline & E_oc ocenění & $\begin{array}{l}\text { Sip_účast_1, Sip_účast_2 } \\
\text { pozvání k účasti }\end{array}$ & \\
\hline & E_poli politický vliv & $\begin{array}{l}\text { Sip_vzoz_1, Sip_vzoz } \\
\text { 2, Sip_vzoz_3 vztahy } \\
\text { k organizaci, zamèstnancům }\end{array}$ & \\
\hline & E_pocne pocit nenahraditelnosti & $\begin{array}{l}\text { Sip_vzkp_1, Sip_vzkp_2 } \\
\text { vztahy ke konečnému př́ijemci }\end{array}$ & \\
\hline & E_str strach, obava & $\begin{array}{l}\text { Sip_vzod vztahy k ostatním } \\
\text { dárcům }\end{array}$ & \\
\hline & $\begin{array}{l}\text { E_warm_1, E_warm_2 dobrý } \\
\text { pocit (warm-glow) }\end{array}$ & & \\
\hline & E_reci reciprocita & & \\
\hline & E_sv svědomí & & \\
\hline & $\begin{array}{l}\text { E_sebeob touha } \\
\text { po sebeobětování }\end{array}$ & & \\
\hline & E_repu reputace & & \\
\hline & $\begin{array}{l}\text { E_oplsp_1, E_oplsp_2 oplátka } \\
\text { společnosti }\end{array}$ & & \\
\hline & E_pp potřeba pomoci & & \\
\hline & E_pnp potřeba někam patřit & & \\
\hline \multirow{4}{*}{$\begin{array}{l}\text { Investiční } \\
\text { motivy }\end{array}$} & I_osko osobní kontakty & & \\
\hline & I_dov dovednosti & & \\
\hline & I_ses socio-ekonomický status & & \\
\hline & I_prpř pracovní príležitosti & & \\
\hline
\end{tabular}

Zdroj: vlastní výzkum 


\subsection{Metody analýzy dat}

K analýze byla použita mnohonásobná lineární regrese a binární logistická regrese.

Mnohonásobná lineární regrese: cílem regresní analýzy je popsat závislost jedné měřitelné veličiny na několika nezávislých proměnných pomocí vhodného (matematického) modelu, který má tvar:

$$
Y=\beta_{0}+\beta_{1} X_{1}+\beta_{2} X_{2}+\ldots+E,
$$

kde $Y$ je závisle proměnná a $X_{1}, X_{2}, \ldots$ jsou nezávisle proměnné, $\beta_{0}$ je absolutní člen regresní funkce a $\beta_{1}, \beta_{2} \ldots$ jsou dílčí regresní koeficienty; $E$ reprezentuje náhodnou složku modelu. Parametry modelu se odhadují metodou nejmenších čtverců.

Binární logistická regrese: vzhledem k charakteru závisle proměnné nebyla lineární regrese vždy vhodná. Pro závisle proměnnou ,,poskytnutí daru“, která nabývala pouze dvou hodnot (0 - dar neposkytl, 1 - dar poskytl), byla použita binární logistická regrese. $\mathrm{V}$ logistické regresi je modelována pravděpodobnost výskytu jevu $p=\mathrm{P}(Y=1)$. Podíl pravděpodobností, že jev nastane/nenastane, se nazývá šance jevu. Logaritmus šance jevu je logit. Vícenásobný model lze zapsat následovně:

$$
\operatorname{logit}=\ln \left(\frac{\pi}{1-\pi}\right)=\beta_{0}+\beta_{1} \mathrm{X}_{1}+\beta_{2} \mathrm{X}_{2} \ldots+\beta_{\mathrm{n}} \mathrm{X}_{\mathrm{n}} .
$$

V logistickém regresním modelu se koeficienty odhadují pomocí metody maximální věrohodnosti. Nástroje vyhodnocení kvality získaných modelů a testování významnosti jeho parametrů jsou proto u použitých postupů poněkud odlišné.

Vzhledem k velkému počtu nezávisle proměnných byla zvolena u obou typů regrese metoda Stepwise, která se používá k nalezení „optimálního“ modelu. Do výpočtu a do modelu vstupují pouze ty proměnné, které jsou statisticky významně vztaženy k proměnné závislé. Metoda postupné regrese vychází ze zkoumání přírůstku regresního (teoretického) součtu čtverců (součet čtverců rozdílu vyrovnaných hodnot od průměru) pomocí sekvenčních F-testů nebo ze zvýšení upraveného indexu determinace. V logistické regresi se za ukazatel statistické významnosti považuje především změna věrohodnosti (resp. jejího logaritmu), tzv. deviance. Proměnné jsou do modelu zařazovány v tom pořadí, v jakém přispívají k největšímu snížení deviance oproti modelům, které je neobsahují.

\section{Teoretická východiska: vnitřní a vnější proměnné ovlivňující dárcovství}

Způsoby našeho myšlení a cítění tvoří nedílnou součást proměnných, které ovlivňují naše rozhodování o poskytnutí daru. Naše politická ideologie, náboženská víra, společenské zájmy a další hodnoty tvoří zdroje různých motivů. Altruismus stojí v pozadí prosociálního chování. Jeho nejvýznamnější charakteristikou je upřednostňování prospěchu ostatních. Mezi nejvýznamnější výzkumy vztahující se k testování altruistických pohnutek lze řadit: Sargeant [1999], Bennett [2003], Kottasz [2004], Smith [2005], Ranganathan a Henley [2008], Bekkers a Wiepking [2010], Marx a Carter [2014]. 
Smith [2005] ve svém díle akcentuje soucit, lítost, empatii a dále sympatii, kterou dnes spíše používáme ve smyslu zalíbení či lásky. Batson [1991] a jeho kolegové dokládají, že lidé, kteří jsou v určitých situacích empatičtější k pocitům ostatních, jsou také ochotnější pomáhat druhým. Smith uvádí, že pokud si přejeme vykonávat dobro pro ostatní, protože to umocňuje naše potěšení (či zmenšuje nelibost vůči něčemu, někomu), nejedná se o morální důvod, či motiv někomu pomáhat. Přesto existuje morálka, která rovněž vyvolává naši starost o druhé, jedná se např. o morální sociální normy, společenská pravidla.

Ve výzkumech nalezneme širokou škálu testovaných egoistických motivů: Becker [1974], Collard [1979], Andreoni [1990], Batson a Shaw [1991], Bekkers a Wiepking [2010]. Dárcovství představuje dobrovolný vznik nákladů pro blaho někoho druhého, avšak u dárce takový akt může vyvolat sebeuspokojení, chválu, úctu a obdiv, sympatie a obdiv druhých. Někteří dárci získávají hmatatelné výhody, jako jsou určité odměny od obdarované organizace (veřejné uznání a poděkování, členství, př́stup na plánové akce apod.), politické výhody, nepřimé tržní výhody atd. V některých př́ipadech můžeme dárcovství považovat za ekvivalent platby „členského př́spěvku“. Jednotlivci $\mathrm{v}$ některých př́ípadech také darují v očekávání obdrženého daru v rámci reciprocity - očekávají vlastní prospěch. Jak uvádí Becker [1974], některé motivy jsou mnohem méně patrné než jiné, napřr. strach z pohrdání ostatními v př́ípadě neposkytnutí daru. Andreoni [1990] předpokládá, že pokud lidé poskytnou dar, prožijí pocit uspokojení (warm-glow).

Výzkumy dokládají, že mnoho filantropických aktivit vzniká v souvislosti s určitou fází našeho života. Je nepravděpodobné, že jednotlivec např. poskytne dar, pokud sám trpí nedostatkem. Některé dary však můžeme nazvat investicí, přestože v daném momentu nám mohou zpo̊sobovat spíše újmu - užitky z nich plynoucí jsou menší než náklady. Setkáváme se např. s mnoha lidmi, kteří poskytují své profesní vědomosti a um, aby pomohli (napřr. v oblasti financí, či práva). Na oplátku získávají kontakty, které jim mohou pomoci v jejich profesním životě, či dovednosti, jejichž prostřednictvím se stávají odborníky ve svém oboru, zvyšují si osobní socio-ekonomický status, a získávají tak lepší pracovní př́ležitosti.

Na teoretické i empirické úrovni bylo provedeno mnoho různorodých výzkumů, které se zaměřovaly na potvrzení či vyvrácení vlivu nepřeberného množství různých determinantů (vnějších proměnných). Podívejme se na ně podrobněji.

\section{- Finanční dostupnost (výše príjmu, vlastnictví nemovitostí, velikost úspor, aj.)}

Vliv finančních proměnných na dárcovství byl testován nap̌r. ve výzkumech: Kitchen [1992], Sargeant [1999], Tiehen [2001], Hasens [2006], Carroll [2005], NCVO [2006], Gittel a Tebaldi [2006], James, Sharpe et al. [2007], James a Jones [2011], Bakina a Heim [2008], Showers et al. [2011], Marx a Carter [2014]. Pozitivní vztah mezi výší př́ijmu a mírou dárcovství potvrzují napřs. Kitchen [1992], Tiehen [2001], Bakina a Heim [2008]. Gittel a Tebaldi [2006] dokládají, že růst př́ijmů na hlavu v dané zemi rovněž zvyšuje průměrnou míru dárcovství na hlavu. Vztah mezi výší příjmu a úrovní dárcovství je pozitivní [NCVO, 2006]; př́ijem významným způsobem ovlivňuje míru dárcovství. Vyšší prříjmová část obyvatel většinou daruje ve větší míře než jiné skupiny obyvatelstva, jako jsou ženy, starší lidé či jednotlivci s vyšším socio-ekonomickým profilem. 


\section{- Daňová politika}

Dan̆ovou politikou země je myšleno zdanění nákladů při poskytnutí daru. Čím více daňové zvýhodnění nabízí př́ležitost snížit placené daně jednotlivcem, tím silnější mají jednotlivci a domácnosti tendenci přispívat na dobročinnost [Dehne et al., 2008].

- Velikost veřejného sektoru

Veřejné financování neziskových organizací rovněž ovlivňuje míru dárcovství [viz Andreoni, 1990; Becker a Lindsay, 1994; Andreoni et al., 2003; Andreoni a Payne, 2011]. Výzkumy potvrzují, že veřejné dotace mohou vytěsnit (crowd-out) soukromé dary. Nicméně na významu tohoto vlivu se výzkumy neshodují [Andreoni a Payne, 2011].

\section{- Počet dětí/členů domácnosti}

Bekkers a Wiepking [2010] dokládají pozitivní vliv dětí na dárcovství ve většině provedených výzkumů. Rovněž Banks a Tanner [1999] potvrzují, že počet dětí v domácnosti má vliv na ochotu darovat, avšak nepodařilo se jim potvrdit vliv počtu dětí na velikost daru. Některé výzkumy se nezaměřovaly na vliv počtu dětí v domácnosti, ale počtu osob v domácnosti.

\section{- Věk}

Věk dárce a jeho výše př́ijmu jsou úzce provázány [viz např. Sargeant, 1999; Hasens, 2006; Kottasz, 2004; Bekkers a Wiepking, 2010; NCVO, 2006; James a Jones, 2011; Marx a Carter 2014]. Dle některých výzkumů [např. Kitchen, 1992] je míra dárcovství závislá především na věku hlavy rodiny. Domácnosti se starší hlavou rodiny darují více, nebot' tato osoba dosahuje většinou vyššího kariérního postu, z něhož většinou plynou vyšší př́ijmy.

\section{- Pohlaví}

Výzkumné zprávy ze sociálních a behaviorálních věd [Snipes a Oswald, 2010] dlouhodobě potvrzují stereotyp, že muži jsou zaměřeni více individualisticky (jak předpokládají tradiční hospodářské teorie), a tudíž je méně pravděpodobné, že budou přispívat na charitativní účely, zatímco ženy jsou orientovány více sociálně. Rovněž Feldman [1985] zastává názor, že ženy mají větší tendenci k pomáhajícímu chování a jsou všímavější ke svému okolí.

\section{- Vzdělání}

Některé výzkumy [viz. Brown a Lankford, 1992; Banks a Tanner, 1999; Tiehen, 2001; Gittell a Tebaldi, 2006; Bekkers a Schuyt, 2008; Showers et al., 2011] dokazují existenci vztahu mezi vzděláním a dárcovstvím. Jednotlivci, kteří získali akademický titul, většinou dosahují na trhu práce vyšších př́ijmů, a díky tomu mohou více přispívat na charitativní účely, mohou být více sociálně uvědomělí, či se mohou cítit povinni přispívat.

\section{- Socio-ekonomický status}

Podle mnohých výzkumů ovlivňuje socio-ekonomický status výrazně míru altruismu jednotlivce, resp. vysoký status člověka snižuje altruistické cítění [viz např. Friedrichs, 1960; Sargeant, 1999; Hasens, 2006; Carroll, 2005; NCVO, 2006; Marx a Carter, 2014]. Proti tomuto názoru však stojí fakt, že socio-ekonomický profil dárce je úzce spojen s výší jeho prŕíjmu. Dle NCVO [2006] nalezneme nejštědřejší dárce v tzv. první skupině 
(manažerské a odborné pozice), kdy daná skupina darovala $57 \%$ všech poskytnutých darů a tvořila $38 \%$ všech dárců.

\section{- Náboženská orientace}

Důležitým faktorem ovlivňujícím dárcovství je náboženská orientace [viz Sargeant, 1999; Eckel a Grossman, 2004; Berger, 2006; Gittell a Tebaldi, 2006; Brown a Ferris, 2007; Bekkers a Schuyt, 2008; Showers et al., 2011; Marx a Carter, 2014]. Mnoho náboženství považuje dárcovství a přsispívání na charitu za morální povinnost jednotlivce. Některá náboženství dokonce nařizují, aby jednotlivci darovali určitou částku z jejich ročního př́ijmu (tzv. desátek).

\section{- Rodinnýstav}

$\mathrm{Na}$ rozdíly $\mathrm{v}$ dárcovství $\mathrm{z}$ hlediska rodinného stavu se zaměřuje řada výzkumů [viz Hasens, 2006; Hrung, 2004; Rooney et al., 2005; Mesch et al., 2006; James, Sharpe et al., 2007; Hughes a Luksetich, 2007; Wiepking a Maas, 2009; Marx a Carter, 2014]. Cílem výzkumů Andreoniho a jeho kolegů [Andreoni, Brown a Rischal, 2003] bylo zjistit, zda se v manželství lidé rozhodují stejně jako osoby svobodné, rozvedené či ovdovělé, nebo zda se jedná spíše o společné rozhodnutí. Autoři došli k závěru, že manželé mezi sebou o dárcovství vedou vyjednávání a jejich společné rozhodnutí je kompromisem, který respektuje z 68 \% manželovy preference a z $26 \%$ manželčiny preference. V uvedeném výzkumu se rovněž autoři snaží postihnout hodnotu nákladů na toto vyjednávání a udávají, že jeho hodnota snižuje darované množství přibližně o $6 \%$.

\section{- Bydliště}

Podle Holahana [1977] je dárcovské rozhodování ovlivněno urbanizační tendencí. Lidé žijící ve městě jsou podle něj sobečtější a individualističtější, zatímco na vesnici, kde jsou lidé zvyklí budovat a udržovat sociální vazby, nalezneme větší tendence lidí k altruistickému chování, z něhož může dárcovství vycházet.

- Politická orientace

Vliv politické orientaci či angažovanosti na dárcovství zkoumal např. Brooks [2002]. $\mathrm{Na}$ základě výsledků svého výzkumu konstatuje, že konzervativní jedinci přispívají na církevní účely více než liberálové, jiné rozdíly autor nenachází.

\section{- Dobrovolnictví a občanská participace}

Účast v komunitě je tvořena vztahy jak formálními (např̀. v organizacích regionálního charakteru - sportovní kluby), tak neformálními (napřr. rodinné návštěvy, starost o staré rodiče aj.). Dobrovolnictví je důležitým aspektem dárcovství, větší míra participace jednotlivce ve společnosti je spojena s vyšší mírou dárcovství. Lidé, kteří jsou zapojeni do sociálních aktivit, dávají také dvakrát až čtyřikrát větší příspěvky než ostatní jednotlivci [Hasens, 2006].

\section{- Rodinné prostředí}

Člověk je ovlivňován svým dětstvím, přístupem rodičů k výchově a jejich vzory. Podle Friedrichse [1960] představuje určitý vliv také sourozenecké prostředí, nebot' člověk, který vyrůstal s více sourozenci má větší potenciál chovat se altruisticky a kooperativně. 
Modely a zkušenosti z mládí mají vliv na modely chování v dospělosti (zda jsme přátelští, jsme tržně-podnikatelsky zaměření, máme přátele na pozicích ředitelů organizací, jsme věřící apod.) [viz Lunn et al., 2001; Simmons, 2004; Bekkers a Wiepking, 2010].

\section{- Efekt přihlížejících}

Rozsáhlý počet experimentů potvrzuje, že připravenost člověka pomoci je ovlivněna velikostí skupiny, jejíž je součástí. S rostoucí velikostí skupiny se snižuje ochota jednotlivce pomoci druhému v nouzi. Člověk v přítomnosti druhých cítí nejistotu a úzkost, protože je druhým na očích.

\section{- Pozvání k účasti}

Přímá žádost o pomoc je častým jevem, který vyvolává dárcovský akt. Pro většinu dárců, je konkrétní žádost o pomoc hlavním důvodem jejich charitativního činu [Hasens, 2006]. Pokud je jednotlivec přímo požádán někým, koho zná, či reprezentantem dané neziskové organizace, je jeho ochota darovat silnější, než pokud je vyzván k účasti jinými, neosobními metodami.

\section{- Vztahy dárce}

Nemalý podíl na výsledku dárcovského rozhodování mají také vztahy potenciálního dárce $\mathrm{k}$ určitým skupinám jako nap̌r. k obdarovávané organizaci a jejím zaměstnancům, ke konečnému př́ijemci, popř. k ostatním dárcům.

\section{- Charakter situace}

Výzvy neziskových organizací se setkávají s pozitivní odezvou obzvláště ve chvílích naléhavosti [viz Isen a Levin, 1972; Kottasz, 2004; Hewstone a Stroebe, 2006; Bekkers a Wiepking, 2010]. Mimořádné události vyžadující okamžitou reakci (nemoc, úmrtí, požár a jiné tragédie, které postihují naše známé či široký okruh lidí) mohou být jak lokálního, regionálního, tak národního i nadnárodního charakteru.

- Fundraisingové metody

Metody, které využívají neziskové organizace k získávání finančních prostředků od dárců, hrají podstatnou roli v míře dárcovství. Určité metody, které přímo oslovují potenciální dárce (např. členství v organizacích, osobní setkání) můžeme charakterizovat jako efektivnější než metody nepř́imé (např. inzerce, poštovní kampaň aj.).

\section{Empirická reflexe: model dárcovského chování}

Data z empirického testování byla podrobena regresní analýze, která si kladla za cíl: 1) vysvětlit rozptyl závisle proměnné; 2) odhadnout vliv každé z nezávisle proměnných na proměnnou závislou, přičemž vliv každé nezávisle proměnné je odhadován tak, že je kontrolováno působení ostatních nezávisle proměnných, které vstupují do modelu; 3) posoudit relativní sílu vlivu jednotlivých proměnných na proměnnou závislou; 4) sestavit regresní rovnici. Regresní analýza všech 69 proměnných byla zpracována pro dvě závisle proměnné: výši daru a darování (tj. zda byl či nebyl poskytnut dar). Následující část př́íspěvku předkládá základní zjištění. 


\subsection{Mnohonásobná lineární regresní analýza}

Následující mnohonásobná lineární regrese zkoumá vztah mezi výší poskytnutého daru a jednotlivými faktory, tj. motivy i determinanty. Výše daru představuje ordinální proměnnou, hodnoty byly pro potřeby analýzy kódovány do deseti kategorií vzestupně podle její výše. Do modelu vstupovalo všech 69 vysvětlujících proměnných, tak jak jsou uvedeny v tabulce 1. Prostřednictvím Stepwise metody byl vybrán v šestém kroku model $(\mathrm{R} 2=0,472)$, který pracoval s následujícími proměnnými: prŕjem respondenta (Ep_fin_1), lítost (A_slit), víra ve spravedlnost (A_visp_1), vztahy k organizaci a zaměstnancům (Sip_vzoz_3), vztahy ke konečnému př́ijemci (Sip_vzkp_2), náboženská orientace (Dp_náb).

Celkový F-test uvedeného modelu je významný na hladině významnosti 0,05 ( $\mathrm{F}=20,885$ při 6 a 140 stupních volnosti).

Dalším výstupem regresní analýzy je tabulka odhadnutých regresních koeficientů (tabulka 2). Hodnota standardizovaného koeficientu Beta nám umožní srovnávat míru vlivu jednotlivých nezávisle proměnných. Odhad absolutního členu modelu je v tabulce označen jako (Constant); odhady regresních parametrů jsou doplněny o směrodatné chyby (Std. Error).

Tabulka 2 | Lineární regrese - regresní koeficienty

\begin{tabular}{|l|c|c|c|c|c|}
\hline \multirow{2}{*}{ Model } & $\begin{array}{c}\text { Nestandardizované } \\
\text { koeficienty }\end{array}$ & $\begin{array}{c}\text { Standardizované } \\
\text { koeficienty }\end{array}$ & $\begin{array}{c}\text { t } \\
\text { statistika }\end{array}$ & Sig. \\
\cline { 2 - 5 } & B & $\begin{array}{c}\text { Std. } \\
\text { Error }\end{array}$ & Beta & \\
\hline (Constant) & 3,199 & 0,677 & & 4,723 & 0,000 \\
\hline $\begin{array}{l}\text { Ep_fin_1 (př́ijem } \\
\text { respondenta) }\end{array}$ & 0,669 & 0,089 & 0,478 & 7,554 & 0,000 \\
\hline A_slit (lítost) & 0,643 & 0,141 & 0,340 & 4,579 & 0,000 \\
\hline $\begin{array}{l}\text { A_visp_1 (víra } \\
\text { ve spravedlnost) }\end{array}$ & $-0,586$ & 0,177 & $-0,247$ & $-3,310$ & 0,001 \\
\hline $\begin{array}{l}\text { Sip_vzoz_3 } \\
\text { (vztahy k org. } \\
\text { a zaměstnancům) }\end{array}$ & $-0,426$ & 0,104 & $-0,283$ & $-4,114$ & 0,000 \\
\hline $\begin{array}{l}\text { Sip_vzkp_2 (vztahy } \\
\text { ke konečnému } \\
\text { pŕíjemci) }\end{array}$ & 0,269 & 0,112 & 0,162 & 2,412 & 0,017 \\
\hline $\begin{array}{l}\text { Dp_náb (náboženská } \\
\text { orientace) }\end{array}$ & $-0,369$ & 0,156 & $-0,146$ & $-2,357$ & 0,020 \\
\hline
\end{tabular}

Zdroj: vlastní výzkum 
Regresní model obsahuje šest vybraných proměnných: prŕijem respondenta (Ep_fin_1), lítost (A_slit), víra ve spravedlnost (A_visp_1), vztahy k organizaci a zaměstnancům (Sip_vzoz_3), vztahy ke konečnému př́ijemci (Sip_vzkp_2), náboženská orientace (Dp_náb). Vybrány tedy byly 2 altruistické motivy a 4 socio-demografické determinanty (z toho 1 ekonomický, 1 demografický, 2 situační).

Konstanta je odhadnuta na přibližně 3 , což znamená, že průměrná hodnota výše daru v námi analyzovaných datech spadá do 3 . velikostní kategorie daru, tj. dle kódování mezi hodnoty $201-500$ Kč. Regresní koeficienty nabývají kladných i záporných hodnot. Kladná hodnota koeficientu znamená, že mezi nezávisle a závisle proměnnou je pozitivní vztah, záporná hodnota indikuje negativní vztah. Při posuzování regresních koeficientů je nezbytné správně vyhodnotit kódování výsledků. U motivů a determinantů byla škála hodnocení následující: 1 - zcela souhlasím až 5 - zcela nesouhlasím. Pokud je tedy znaménko u koeficientu kladné (kladný vliv), znamená to posun na škále od 1 směrem k 5 tj. rostoucí míru neztotožnění se.

Pozitivní vztah lze nalézt u proměnných: př́ijem respondenta, lítost a vztahy ke konečnému př́ijemci. Tzn. čím vyšší je čistý příjem, čím větší je míra neztotožnění se s motivem lítost, či determinantem vztahy ke konečnému př́ijemci, tím vyšší je hodnota poskytnutého daru. Čím nižší je míra ztotožnění se s motivem víra ve spravedlnost, determinantem vztahy k organizaci a zaměstnancům či náboženské orientace, tím vyšší je hodnota poskytnutého daru. Dané výsledky analýzy potvrzují předešlá zjištění autorů [např. Hladká a Hyánek, 2015], která se zabývají rozdílným vlivem vysvětlujících proměnných na ochotu, míru a frekvenci darování. Autoři dochází k závěru, že proměnné, které statisticky významným způsobem ovlivňují např. ochotu darovat a lze je označit spíše za motivy altruistické, jsou zcela odlišné od proměnných, které mají vliv na míru, tj. výši daru. Čím více lidé potlačují své altruistické motivy a čím více jsou hnáni motivy egoistickými (např. možnost odpočtu daru z daní), tím větší finanční obnos darují. Dle hodnot koeficientů Beta je zřejmé, že na výši poskytnutého daru má největší vliv př́ijem respondenta $(0,478)$.

$\mathrm{Z}$ údajů v tabulce lze sestavit následující regresní rovnici:

$$
\begin{gathered}
\text { Y }(\text { vyse daru })=3,199+0,669 \times \text { Ep_fin_1 }+0,643 \times \text { A_slit }-0,586 x \text { A_visp_1 } \\
\text { - 0,426xSip_vzoz_3 }+0,269 \times \text { xip_vzkp_2 }-0,369 \times \text { Dp_náb. }
\end{gathered}
$$

\subsection{Binární logistická regresní analýza}

Binární logistická regrese zkoumá vztah mezi darováním (nabývá dvou hodnot, 0 - respondent dar neposkytl, 1 - respondent dar poskytl) a jednotlivými uvažovanými faktory, které jsou uvedeny $\mathrm{v}$ tabulce 1.

Tabulka 3 obsahuje klesající hodnotu deviance při postupném zařazování vysvětlujících proměnných do modelu metodou Stepwise a dále rostoucí hodnoty Cox-Snellovy a Nagelkerkeho statistiky. Jde o pseudo R-square statistiky, ve druhém př́ípadě z intervalu od 0 do 1 . Dosažená hodnota je uspokojivě vysoká. 
Tabulka 3 | Logistická regrese - model summary

\begin{tabular}{|l|c|c|c|}
\hline Krok & $\mathbf{- 2}$ Log likelihood & Cox \& Snell R Square & Nagelkerke R Square \\
\hline $\mathbf{1}$ & 354,977 & 0,174 & 0,232 \\
\hline $\mathbf{2}$ & 330,072 & 0,240 & 0,320 \\
\hline $\mathbf{3}$ & 311,477 & 0,286 & 0,382 \\
\hline $\mathbf{4}$ & 294,74 & 0,326 & 0,434 \\
\hline $\mathbf{5}$ & 285,238 & 0,347 & 0,462 \\
\hline $\mathbf{6}$ & 280,753 & 0,357 & 0,475 \\
\hline $\mathbf{7}$ & 275,809 & 0,367 & 0,490 \\
\hline $\mathbf{8}$ & 271,539 & 0,376 & 0,502 \\
\hline
\end{tabular}

Zdroj: vlastní výzkum

Další způsob, jak ocenit adekvátnost modelu, spočívá v porovnání pozorovaných a modelem predikovaných zařazení do kategorií binární vysvětlované proměnné, které je vyjádřeno klasifikační tabulkou (tabulka 4). Zařazení je přitom provedeno tak, že pokud $($ odhad $\pi)<0,5, Y=0 ; \mathrm{v}$ opačném případě $\mathrm{Y}=1$. Součet případů na hlavní diagonále tabulky udává, kolik př́ípadů bylo klasifikováno správně. Z klasifikační tabulky se dozvídáme, že do kategorie závisle proměnné s kódem nula bylo správně zařazeno 77,7 \% př́ípadů, do kategorie s kódem jedna 77,9\% př́ípadů a celkově bylo správně zařazeno 77,8 \% př́ipadů, což ukazuje na celkem dobrou diskriminační sílu modelu.

Tabulka 4 | Logistická regrese - klasifikační tabulka

\begin{tabular}{|l|l|r|r|c|}
\hline \multicolumn{2}{|c|}{} & \multicolumn{3}{c|}{ Skutečnost } \\
\cline { 3 - 5 } Test & NE & ANO & $\begin{array}{c}\text { Procenta } \\
\text { celkem }\end{array}$ \\
\hline \multirow{3}{*}{ Krok 8 } & NE & 115 & 33 & 77,7 \\
\cline { 2 - 5 } & ANO & 33 & 116 & 77,9 \\
\cline { 2 - 5 } & $\begin{array}{l}\text { Procenta } \\
\text { celkem }\end{array}$ & & & 77,8 \\
\hline
\end{tabular}

Zdroj: vlastní výzkum

V logistickém regresním modelu lze jednotlivé koeficienty interpretovat jako změnu logitu spojenou s jednotkovou změnou příslušné nezávisle proměnné za předpokladu, že hodnoty ostatních proměnných se nezmění; po odlogaritmování pak parametr určuje velikost změny šance při jednotkové změně př́íslušné nezávisle proměnné.

Hodnota regresního koeficientu B sama o sobě nestačí k vyslovení závěru, že daná nezávisle proměnná je významná pro predikci či vysvětlení závisle proměnné. $\mathrm{K}$ tomu je potřeba ověřit významnost parametru Waldovým testem. Výchozí model 
s 69 vysvětlujícími proměnnými byl metodou Stepwise redukován na model tvořený 8 proměnnými. Jedná se o následující faktory: 5 altruistických motivů (náklonnost A_nák1, soucit a solidarita A_ss, vděčnost A_vdě, sociální odpovědnost A_socod_2, morální povinnost A_mopo_2), 2 egoistické motivy (sebestřrednost E_sebe, dobrý pocit E_warm_1) a 1 socio-demografický determinant (věk Dp_vek).

Všechny koeficienty v modelu jsou statisticky významné (hladina významnosti je stále 0,05$)$. To znamená, že všechny uvažované proměnné mají významný vliv na predikci či na vysvětlení závisle proměnné. Největší vliv na změnu logitu má přitom věk (exp B pro proměnnou věk je 1,547). Stejně jako v lineární regresi je zapotřebí si uvědomit, že zvýšení nezávisle proměnné o jednotku znamená vyšší míru neztotožnění se s daným motivem či determinantem. Tedy na př́kladu: dobrý pocit $\left(E \_w a r m ~ 1\right)=-0,812$, tj. zvýší-li se míra neztotožnění se s motivem dobrý pocit, klesne míra šance, že respondent bude darovat.

Tabulka 5 | Logistická regrese - regresní koeficienty

\begin{tabular}{|l|l|c|c|c|c|c|c|}
\hline \multicolumn{2}{|c|}{} & $\begin{array}{c}\text { Koeficient } \\
\text { B }\end{array}$ & $\begin{array}{c}\text { Std. } \\
\text { Error }\end{array}$ & $\begin{array}{c}\text { Waldova } \\
\text { statistika }\end{array}$ & df & Sig. & $\begin{array}{c}\text { Koeficient } \\
\text { Exp(B) }\end{array}$ \\
\hline \multirow{5}{*}{} & A_nákl (náklonnost) & $-0,316$ & 0,155 & 4,187 & 1 & 0,041 & 0,729 \\
\cline { 2 - 7 } & $\begin{array}{l}\text { A_ss (soucit } \\
\text { a solidarita) }\end{array}$ & 0,407 & 0,176 & 5,334 & 1 & 0,021 & 1,503 \\
\cline { 2 - 7 } & A_vdě (vděčnost) & 0,392 & 0,119 & 10,905 & 1 & 0,001 & 1,479 \\
\hline \multirow{4}{*}{ Krok 8 } & $\begin{array}{l}\text { A_socod_2 (sociální } \\
\text { odpovědnost) }\end{array}$ & $-0,375$ & 0,170 & 4,883 & 1 & 0,027 & 0,687 \\
\cline { 2 - 7 } & $\begin{array}{l}\text { A_mopo_2 (morální } \\
\text { povinnost) }\end{array}$ & $-0,504$ & 0,139 & 13,115 & 1 & 0,000 & 0,604 \\
\cline { 2 - 8 } & $\begin{array}{l}\text { E_sebe } \\
\text { (sebestřednost) }\end{array}$ & 0,434 & 0,117 & 13,648 & 1 & 0,000 & 1,543 \\
\cline { 2 - 8 } & $\begin{array}{l}\text { E_warm_1 (dobrý } \\
\text { pocit) }\end{array}$ & $-0,812$ & 0,198 & 16,884 & 1 & 0,000 & 0,444 \\
\cline { 2 - 8 } & Dp_Vek (věk) & 0,436 & 0,150 & 8,446 & 1 & 0,004 & 1,547 \\
\hline & Konstanta & 0,288 & 0,759 & 0,144 & 1 & 0,705 & 1,333 \\
\hline
\end{tabular}

Zdroj: vlastní výzkum

Mezi proměnné, které signifikantním způsobem zvyšují šanci na darování u respondentů dle vybraného regresního modelu, patř́i motivy náklonnost, sociální odpovědnost, morální povinnost, dobrý pocit, věk. Mezi proměnné, které signifikantním způsobem snižují šanci na darování u respondentů dle vybraného regresního modelu, patří motivy slitování, vděčnost a sebestřednost.

$\mathrm{Z}$ údajů v tabulce lze sestavit následující logistickou regresní rovnici:

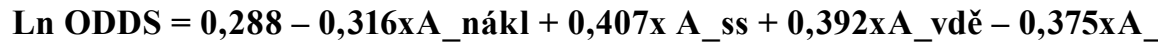
socod_2-0,504xA_mopo_2 $+0,434 x E \_s e b e-0,812 \times E$ warm_1 $+0,436 x D p \_v e k$. 


\section{Závèr}

Problematika dárcovství nebyla zkoumána do té doby, než vzniklo pole studií neziskového sektoru. V České republice dosud všeobecná teorie dárcovství a dárcovského chování neexistuje, což je způsobeno nedostatkem provedených multidisciplinárních výzkumů, fragmentizací výzkumných otázek a nedostatkem solidních teoretických podkladů. Článek se zabývá faktory ovlivňujícími akt rozhodnutí o poskytnutí daru. Tyto faktory jsou ovlivňovány jednak vnitřními pohnutkami, motivy, ale také proměnnými, které jsou dané (a tedy víceméně neovlivnitelné) prostředím, v němž žijeme, vyrůstáme a vstupujeme do vzájemných souvislostí s procesem darování.

V práci je analyzován soubor dat, který vznikl nenáhodným výběrem (konkrétně př́iležitostným výběrem), což umožnilo v intencích výzkumného šetření získat data potřebná pro analýzu, která nejsou zobecňována, ale jsou pouze pomocná. Výzkumné šetření tak bylo pojato jako předběžný průzkum či pilotní studie, která se používá k sondování v prostředí, o kterém máme málo poznatků a potřebujeme se $\mathrm{v}$ něm předběžně zorientovat. Na nevelkém a nahodile vybraném vzorku se autoři pokouší zjistit, jaké charakteristiky mohou mít jednotky, které je třeba zkoumat.

Přri empirickém testování se potvrdily předpoklady charakteristické pro tento typ výzkumu. Při zjištování jakýchkoliv dat neprímým způsobem, obzvláště dat vztahujících se k lidskému chování, je nanejvýš důležité zkoumaný jev vhodně operacionalizovat Při interpretaci zjištěných výsledků v rámci provedeného šetření bylo podstatné, jak zněla a byla chápána daná otázka (tzv. validita otázky). K jednomu motivu mohlo být vztaženo několik otázek s rozličným zněním. Výsledky dokládají, že rovněž pro jeden motiv či determinant se mohly objevit rozdílná (někdy až protichůdná) zjištění v souvislosti se zněním otázky. Někdy tak byl daný motiv či determinant $\mathrm{v}$ rámci jedné otázky potvrzen, $\mathrm{v}$ rámci druhé nikoli.

Chování je ve svém směru a síle determinováno motivy, ale jeho způsob je determinován i situačními faktory: chování se přizpůsobuje situaci, a tak v různých situacích může být dosaženo téhož cíle [Nakonečný, 1999]. Dané tvrzení může být vztaženo i na dárcovské chování. To je ovlivňováno řadou zjevných i skrytých vnitřních či vnějších proměnných, mezi nimiž existují vždy různé kauzální vztahy. Je tedy velmi obtížné předložit ucelený přehled všech proměnných pro jakoukoliv situaci, pro jakýkoliv výzkumný vzorek či exaktně definovat vazby závislosti. Ve skutečnosti mohou rozhodování o poskytnutí daru ovlivňovat i proměnné, které si jednotlivec nemusí uvědomovat a které tak činí jeho chování obtížně popsatelným. Lidské chování je náhodné a lze jej velmi těžko modelovat. Při posuzování lidského jednání tak bývá ponechán určitý prostor pro nevysvětlitelnou část. Výsledky lineární regrese dosahují $\mathrm{R} 2=0,472$. Dle údaje R2 vysvětluje model $47 \%$ variability závisle proměnné. To znamená, že téměř $50 \%$ variability výše poskytnutého daru se nám podařilo vysvětlit prostřednictvím námi zvolených proměnných, zbytek variability je zapotřebí hledat $\mathrm{v}$ jiných proměnných. Pro logistickou regresi bylo navrženo mnoho analogů ke koeficientu determinace R2, který byl uveden v lineární regresi, jedná se o R2 Coxové a Snella. Hodnota R2 Coxové a Snella je 0,376, hodnota R2 Nagelkerka je 0,502.

Ve vztahu k výzkumnému šetření byla předložena odpověd’ na následující výzkumnou otázku - RQ1: Které determinanty statisticky významně ovlivňují ochotu darování? Ve snaze neposkytnout při analýze dat pouze výsledky vycházející z bivariačních vztahů, 
bylo všech 69 proměnných podrobeno regresní analýze. Prostřednictvím analýzy byl hledán model závislosti výše daru na lineární kombinaci hodnot více nezávislých proměnných. Byl odhadnut vliv každé z nezávisle proměnných na proměnnou závislou, přičemž vliv každé nezávisle proměnné je odhadován tak, že bylo kontrolováno působení ostatních nezávisle proměnných vstupujících do modelu.

Výsledky popsané v tomto článku dokládají, že při zjišstování ,úrovně“ dárcovství $\mathrm{v}$ dané společnosti je velmi podstatné stanovení výzkumné otázky, tedy zda se zaměřujeme na dárce nejochotnější, nejštědřejší či pravidelné dárce. Přri porovnání ochoty, míry a frekvence darování se ukazuje, že výsledky mohou být rozdílné; dárci nejochotnější nemusí být dárci nejštědřejší, dárci pravidelní nemusí být dárci nejochotnější, dárci nejštědřejší nemusí být dárci pravidelní. Tento fakt je nutné zohlednit při následné interpretaci výsledků.

Z výsledků realizované lineární regresní analýzy vyplývá, že statisticky významný vliv na míru dárcovství má šest proměnných: 2 altruistické motivy (lítost, víra ve spravedlnost) a 4 socio-demografické determinanty - z toho 1 ekonomický (př́ijem respondenta), 1 demografický (náboženská orientace), 2 situační (vztahy k organizaci a zaměstnancům, vztahy ke konečnému př́ijemci). Pozitivní vztah lze nalézt u proměnných př́ijem respondenta, lítost a vztahy ke konečnému př́ijemci. Čím vyšší je tedy čistý př́ijem, čím větší je míra neztotožnění se s motivem lítost, či determinantem vztahy ke konečnému př́ijemci, tím vyšší je hodnota poskytnutého daru. $Z$ výsledků binární logistické regrese vyplývá, že mezi proměnné, které signifikantním způsobem zvyšují šanci na darování u respondentů, patří motivy náklonnost, sociální odpovědnost, morální povinnost, dobrý pocit, a demografický determinant věk. Mezi proměnné, které signifikantním způsobem snižují šanci na darování u respondentů dle vybraného regresního modelu, patří motivy slitování, vděčnosti a sebestřednosti.

Práce ukázala, že v rámci subjektivní racionality je možné dojít ke konkrétním závěrům, vzhledem k procesu poskytování darů, které jsou realitě blíže než tradiční vysvětlení prostřednictvím předpokladů a východisek neoklasické ekonomie. Za jeden z teoretických př́nosů lze označit verifikaci platnosti či neplatnosti faktorů ovlivňujících dárcovství na vybraném vzorku v České republice oproti výsledkům z dosud realizovaných zahraničních výzkumných studií, tak jak je uvedeno v teoretické části tohoto textu.

Značné množství jednotlivých motivů vybízí k zamyšlení, zda by bylo možné vysvětlit proces dárcovského rozhodování prostřednictvím menšího počtu proměnných, zda existují určité kombinace vlivů jednotlivých motivů. V návaznosti na toto tvrzení autoři článku navrhují provést faktorovou analýzu a redukci dat s cílem odhalit skryté souvislosti.

\section{Literatura}

ANDREONI, J., 1990. Impure Altruism and Donations to Public Goods: A Theory of Warm-Glow Giving. The Economic Journal, 100(401), 464-477, https://doi.org/10.2307/2234133

ANDREONI, J., BROWN, E. a RISCHALL, I., 2003. Charitable Giving by Married Couples: Who Decides and Why Does It Matter? The Journal of Human Resources, 38(1), 111-133, https://doi.org/10.2307/1558758

ANDREONI, J. a PAYNE, A., 2011. Is Crowding Out Due Entirely to Fundraising? Evidence from a Panel of Charities. Journal of Public Economics, 95(5-6), 334-343, https://doi.org/10.3386/w16372 
BAKINA, J. a HEIM, B., 2008. How Does Charitable Giving Respond to Incentives and Income? Dynamic Panel Estimates Accounting for Predictable Changes in Taxation. SSRN Electronic Journal, 14237, https://doi.org/10.3386/w14237

BANKS, J. a TANNER, S., 1999. Patterns in Household Giving: Evidence from U.K. Data. Voluntas: International Journal of Voluntary and Nonprofit Organizations, 10(2), 167-178, https://doi.org/10.1023/A:1021477922789

BATSON, C. D. a SHAW, L. L., 1991. Evidence for Altruism: Toward a Pluralism of Prosocial Motives. Psychological Inquiry, 2(2), 207-227, https://doi.org/10.1207/s15327965pli0202_1

BECKER, G. S., 1974. A Theory of Social Interaction. Journal of Political Economy, 82(6), 1063-1093, https://doi.org/10.3386/w0042

BECKER, E. a LINDSAY, C. M., 1994. Does the Government Free Ride? The Journal of Law and Economics, 37(1), 277-296, https://doi.org/10.1086/467314

BEKKERS, R. A SCHUYT, T., 2008. And Who Is Your Neighbor? Explaining Denominational Differences in Charitable Giving and Volunteering in the Netherlands. Review of Religious Research, 50(1), 74-96. ISSN 0034673X.

BEKKERS, R. a WIEPKING, P., 2010. A Literature Review of Empirical Studies of Philanthropy: Eight Mechanisms That Drive Charitable Giving. Nonprofit and Voluntary Sector Quarterly, 40(5), 924-973, https://doi.org/10.1177/0899764010380927

BENNETT, R., 2003. Factors Underlying the Inclination to Donate to Particular Types of Charity. International Journal of Nonprofit and Voluntary Sector Marketing, 8(1), 12-29, https://doi.org/10.1002/nvsm.198

BERGER, I. E. et al., 2006. The Influence of Religion on Philanthropy in Canada. VOLUNTAS: International Journal of Voluntary and Nonprofit Organizations, 17(2), 21-67, https://doi.org/10.1007/s11266-006-9007-3

BROOKS, A. C., 2002. Welfare Receipt and Private Charity. Public Budgeting and Finance, 22(3), 101-114, https://doi.org/10.1111/1540-5850.223083

BROWN, E. a FERRIS, J. M., 2007. Social Capital and Philanthropy: An Analysis of the Impact of Social Capital on Individual Giving and Volunteering. Nonprofit and Voluntary Sector Quarterly, 36(1), 85-99, https://doi.org/10.1177/0899764006293178

BROWN, E. a LANKFORD, H., 1992. Gifts of Money and Gifts of Time Estimating the Effects of Tax Prices and Available Time. Journal of Public Economics, 47(3), 321-341, https://doi.org/10.1016/0047-2727(92)90032-B

CARROLL, J. et al., 2005. An Econometric Analysis of Charitable Donations in the Republic of Ireland. The Economic and Social Review, 36(3), 229-249. ISSN 0012-9984.

COLLARD, D., 1979. Altruism and Economy: A Study in Non-Selfish Economics. New York: Oxford University Press. ISBN 978-0855202439.

DEHNE, A. et al., 2008. Taxation of Nonprofit Associations in an International Comparison: An International Comparison. Nonprofit and Voluntary Sector Quarterly, 37(4), 709-729, https://doi.org/10.1177/0899764008315545

ECKEL, C. C. a GROSSMAN, P. J., 2004. Giving to Secular Causes by the Religious and Nonreligious: An Experimental Test of the Responsiveness of Giving to Subsidies. Nonprofit and Voluntary Sector Quarterly, 33(2), 271-289, https://doi.org/10.1177/0899764004263423

FELDMAN, R. S., 1985. Social Psychology: Theories, Research, and Applications. New York: McGraw-Hill. ISBN 00-702-0392-X. 
FRIEDRICHS, R. W., 1960. Alter Versus Ego: An Exploratory Assessment of Altruism. American Sociological Review, 25(4), 321-330, https://doi.org/10.2307/2092934

GITTELL, R. a TEBALDI, E., 2006. Charitable Giving: Factors Influencing Giving in U.S. States. Nonprofit and Voluntary Sector Quarterly, 35(4), 721-736, https://doi.org/10.1177/0899764006289768

HASENS, J. J, O'HERLIHY, M. A. a SCHERVISH, P. G., 2006. Charitable Giving: How Much, By Whom, To What, and How? In Steinberg, R. a Powell, W. W. (eds.). The Non Profit Sector: A Research Handbook (2nd ed.). Yale Press, 552-567. ISBN 978-0300109030.

HEWSTONE, M. a STROEBE, W., 2006. Sociální psychologie: moderní učebnice sociální psychologie. Praha: Portál. ISBN 80-736-7092-5.

HLADKÁ, M. a HYÁNEK, V., 2015. Motives for Donating: What Inspires Our Decisions to Make a Donation to Non-profit Organizations? Národohospodářský obzor, 4, 357-382, https://doi.org/10.1515/revecp-2015-0026

HLADKÁ, M. a HYÁNEK, V., 2016. Explanation of the Donor Decision-making Process in the Czech Republic through a Combination of Influences of Individual Motives. European Financial and Accounting Journal, 1, 23-37, https://doi.org/10.18267/j.efaj.151

HOLAHAN, CH. J., 1977. Effects of Urban Size and Heterogeneity on Judged Appropriateness of Altruistic Responses: Situational vs. Subject Variables. Sociometry, 40(4), 378-382, https://doi.org/10.2307/3033488

HRUNG, W. B., 2004. After-Life Consumption and Charitable Giving. American Journal of Economics and Sociology, 63(3), 731-745, https://doi.org/10.1111/j.1536-7150.2004.00312.x

HUGHES, P. a LUKSETICH, W., 2007. Income Volatility and Wealth: The Effect on Charitable Giving. Nonprofit and Voluntary Sector Quarterly, 37(2), 264-280, https://doi.org/10.1177/0899764007310416

ISEN, A. M. a LEVIN, P. F., 1972. Effect of Feeling Good on Helping: Cookies and Kindness. Journal of Personality and Social Psychology, 21(3), 384-388, https://doi.org/10.1037/h0032317

JAMES, R. a JONES, K., 2011. Tithing: An Examination of Religious Charitable Giving in America. Applied Economics, 43(19), 2441-2450, https://doi.org/10.1080/00036840903213384

JAMES, R. N., SHARPE, L. D. et al., 2007. The "Sect Effect" in Charitable Giving: Distinctive Realities of Exclusively Religious Charitable Givers. American Journal of Economics and Sociology, 66(4), 697-726, https://doi.org/10.1111/j.1536-7150.2007.00536.x

KITCHEN, H., 1992. Determinants of Charitable Donations in Canada: A Comparison Over Time. Applied Economics, 24(7), 709-713, https://doi.org/10.1080/00036849200000039

KOTTASZ, R., 2004. How Should Charitable Organisations Motivate Young Professionals to Give Philanthropically? International Journal of Nonprofit and Voluntary Sector Marketing, 9(1), 9-27, https://doi.org/10.1002/nvsm.230

LUNN, J. et al., 2001. Relationships Among Giving, Church Attendance, and Religious Belief: The Case of the Presbyterian Church (USA). Journal for the Scientific Study of Religion, 40(4), 765-775, https://doi.org/10.1111/0021-8294.00091

MARX, J. a CARTER, V., 2014. Factors Influencing US Charitable Giving During the Great Recession: Implications for Nonprofit Administration. Administrative Sciences, 4(3), 350-372, https://doi.org/10.3390/admsci4030350

MESCH, D. J. et al., 2006. The Effects of Race, Gender, and Marital Status on Giving and Volunteering in Indiana. Nonprofit and Voluntary Sector Quarterly, 35(4), 565-587, https://doi.org/10.1177/0899764006288288 
NCVO (National Council for Voluntary Organisations), 2006. UK Giving 2005/06: Results of the 2005/06 Survey of Individual Charitable Giving in the UK [online]. [cit. 1. 5. 2014]. Dostupné z: http://www.ncvovol.org.uk/uploadedFiles/NCVO/Research/UK\%20giving\%202005-06.pdf

RANGANATHAN, S. K. a HENLEY, W. H., 2008. Determinants of Charitable Donation Intentions: A Structural Equation Model. International Journal of Nonprofit and Voluntary Sector Marketing, 13(1), 1-11, https://doi.org/10.1002/nvsm.297

ROONEY, P. M. et al., 2005. The Effects of Race, Gender, and Survey Methodologies on Giving in the US. Economics Letters, 86(2), 173-180, https://doi.org/10.1016/j.econlet.2004.06.015

SARGEANT, A., 1999. Charitable Giving: Towards a Model of Donor Behaviour. Journal of Marketing Management, 15(4), 215-238, https://doi.org/10.1362/026725799784870351

SHOWERS, V. E. et al., 2011. Charitable Giving Expenditures and the Faith Factor. American Journal of Economics and Sociology, 70(1), 152-186, https://doi.org/10.1111/j.1536-7150.2010.00767.x

SIMMONS, W. O., 2004. Does Government Spending Crowd Out Donations of Time and Money? Public Finance Review, 32(5), 498-511, https://doi.org/10.1177/1091142104264364

SMITH, A., 2005. Teorie mravních citů. Praha: Liberální institut. ISBN 80-863-8938-3.

SNIPES, R. L. a OSWALD, L. S., 2010. Charitable Giving to Not-for-Profit Organizations: Factors Affecting Donations to Non-Profit Organizations. Innovative Marketing, 6(1), 73-80. ISSN 1814-2427.

TIEHEN, L., 2001. Tax Policy and Charitable Contributions of Money. National Tax Journal, 54(4), 707-823, https://doi.org/10.17310/ntj.2001.4.01

WIEPKING, P. a MAAS, I., 2009. Resources That Make You Generous: Effects of Social and Human Resources on Charitable Giving. Social Forces, 87(4), 1973-1995, https://doi.org/10.1353/sof.0.0191 